\title{
Efecto de la coinfección por virus de la influenza y bacterias en el daño al hospedero
}

\author{
Ana María Castro, ${ }^{*}$ Carlos Cabello-Gutiérrez, ${ }^{2}$ Evelyn Pulido-Camarillo, ${ }^{3}$ Alexis E. García-García ${ }^{1}$ y \\ Armando Pérez-Torres ${ }^{3}$ \\ ${ }^{1}$ Universidad Nacional Autónoma de México, Facultad de Medicina, Departamento de Salud Pública; '2aboratorio de Virología, Instituto Nacional \\ de Enfermedades Respiratorias; ${ }^{3}$ Universidad Nacional Autónoma de México, Facultad de Medicina, Departamento de Biología Celular y Tisular. \\ Ciudad de México, México
}

\section{Resumen}

Antecedentes: La infección por el virus de la influenza con frecuencia se complica con una infección bacteriana, coinfección que provoca cuadros graves de neumonía, la cual puede ocasionar la muerte si no es tratada en forma oportuna. Objetivo: Demostrar en modelos animales que la coinfección por el virus de la influenza y bacterias que afectan el tracto respiratorio ocasiona daño multisistémico. Método: Se formaron seis grupos de ratones: un grupo control, uno infectado de virus de la influenza, dos infectados de bacterias: Haemophilus influenzae y Streptococcus pneumoniae, respectivamente; y dos coinfectados de virus de la influenza y Haemophilus influenzae y Streptococcus pneumoniae, respectivamente. Resultados: De los seis grupos de ratones, solo en el grupo coinfectado de virus de la influenza y Streptococcus pneumoniae se observó daño en órganos torácicos y abdominales. En todos los grupos se encontró disminución de los niveles séricos de las citocinas, mayor en los ratones coinfectados. Conclusiones: Los grupos de ratones infectados solo de Streptococcus pneumoniae o el virus de la influenza no presentaron daños, lo cual indica que la coexistencia de estas infecciones fue la que ocasionó el daño en el grupo de ratones coinfectados.

PALABRAS CLAVE: Influenza. Infección bacteriana. Coinfección. Citocinas proinflamatorias.

\section{Effect of coinfection with influenza virus and bacteria on host damage}

\begin{abstract}
Background: Influenza virus infection is often complicated by a bacterial infection, with this coinfection causing severe pneumonia. If not timely treated, the disease can cause death. Objective: To demonstrate, in animal models, that coinfection with influenza virus and bacteria that affect the respiratory tract causes multisystemic damage. Method: Six groups of mice were formed: a control group, one infected with the influenza virus, two infected with bacteria: Haemophilus influenzae and Streptococcus pneumoniae, respectively; and two co-infected with influenza virus and Haemophilus influenzae or Streptococcus pneumoniae, respectively. Results: Of the six groups of mice, only the group co-infected with influenza virus and Streptococcus pneumoniae showed damage to thoracic and abdominal organs. A decrease in serum cytokine levels was found in all study groups, which was more pronounced in the co-infected mice. Conclusions: The groups of mice infected with Streptococcus pneumoniae or influenza virus alone showed no damage, which indicates that coexistence of these infections caused the damage in the group of co-infected mice.
\end{abstract}

KEY WORDS: Influenza. Bacterial infection. Coinfection. Pro-inflammatory cytokines.

Correspondencia:

*Ana María Castro

E-mail: amcastro@ unam.mx
Fecha de recepción: 15-10-2019

Fecha de aceptación: 25-02-2020

DOI: 10.24875/GMM.20005582
Gac Med Mex. 2020;156:273-278

Disponible en PubMed

www.gacetamedicademexico.com

0016-3813/@ 2020 Academia Nacional de Medicina de México, A.C. Publicado por Permanyer. Este es un artículo open access bajo la licencia CC BY-NC-ND (http://creativecommons.org/licenses/by-nc-nd/4.0/). 


\section{Introducción}

Se ha documentado que los virus y las bacterias son los principales agentes etiológicos en las infecciones de origen comunitario. ${ }^{1}$ Las infecciones del tracto respiratorio inferior generalmente se inician con una infección viral (los virus sincitial respiratorio, de la influenza, de la parainfluenza y adenovirus son los agentes causales más comunes'); sin embargo, con frecuencia se complican con una infección bacteriana, combinación que puede desencadenar cuadros graves de neumonía. Entre las bacterias que con mayor frecuencia causan neumonía se han identificado Streptococcus pneumoniae (S. pneumoniae), Haemophilus influenzae (H. influenzae), Staphylococcus aureus (S. aureus) y Streptococcus pyogenes (S. pyogenes).

En 2016, la Organización Mundial de la Salud informó que la neumonía constituyó la principal causa de mortalidad infantil en el mundo. Se calcula que en 2015 causó la muerte de aproximadamente 920136 niños menores de cinco años, es decir, ocasionó $15 \%$ de todas las defunciones de niños menores de cinco años en todo el mundo. ${ }^{2}$ En México, las infecciones del tracto respiratorio continúan representando una de las 10 primeras causas de morbilidad y mortalidad en ese grupo poblacional.

Las infecciones respiratorias agudas inicialmente afectan el tracto respiratorio superior, pero, dependiendo del patógeno y del hospedero, pueden diseminarse al tracto respiratorio inferior y causar neumonía. La influenza, cuyo agente etiológico es el virus de la influenza, es una enfermedad respiratoria aguda muy contagiosa, que afecta a todos los grupos de edad y puede ser más grave en niños y ancianos. La infección se transmite de persona a persona mediante los aerosoles generados por la tos o el estornudo de personas enfermas, los cuales infectan las células epiteliales del tracto respiratorio. A pesar del uso de vacunas, el impacto de las epidemias invernales continúa siendo importante en la población mundial.

En la pandemia de 2018 por el virus de la influenza, la causa principal de muerte fue la infección bacteriana secundaria; ${ }^{3}$ estudios retrospectivos señalaron que fallecieron de 50 a 100 millones de individuos, de los cuales $70 \%$ fue positivo a $S$. pneumoniae. ${ }^{4}$ Se ha demostrado clara predisposición de coinfección por el virus de la influenza y esa bacteria en pandemias posteriores, incluyendo la más reciente, en 2009, por el virus de la influenza H1N1; el índice de hospitalización osciló entre 10 y $55 \%$ y la mortalidad se debió a S. pneumoniae. ${ }^{5}$

Se observó que el virus de la influenza responsable de la pandemia de 1918 provocaba daño grave en pulmón, tipificado por bronquitis, bronquiolitis, alveolitis, predominio de neutrófilos y edema agudo en los alvéolos, así como presencia de células inflamatorias y células muertas. ${ }^{6}$

El daño al tracto respiratorio ocasionado por la coinfección se encuentra documentado. Se ha propuesto que los cambios en el tracto respiratorio causados por el virus de la influenza -entre ellos daño epitelial, alteraciones en la función respiratoria y exposición de los receptores del sistema inmunitario- preparan a la vía aérea superior para la infección bacteriana secundaria. ${ }^{7}$ La gravedad de la enfermedad respiratoria se incrementa por la conjunción de la coinfección y la alteración de la respuesta inmunitaria innata. ${ }^{5}$

Una vez que $S$. pneumoniae ingresa al tracto respiratorio se activa la respuesta inmunitaria innata, en la que participan los macrófagos alveolares liberando citocinas y quimiocinas proinflamatorias, las cuales atraen y reclutan células polimorfonucleares y mononucleares en los alvéolos y el parénquima pulmonar, ${ }^{8}$ con lo que se inicia el proceso inflamatorio propio de la enfermedad. Si la infección no es tratada en forma oportuna, evoluciona hasta ocasionar la muerte del paciente debido a falla multisistémica, la cual se puede acompañar de alteraciones en la coagulación, principalmente sangrado de mucosas, evidenciado por sangre en heces y orina.

Durante las pandemias de influenza anteriores a la de 2009, las coinfecciones bacterianas causadas por $S$. pneumoniae, $H$. influenzae, $S$. aureus y estreptococos del grupo A contribuyeron de forma importante a la morbilidad y mortalidad. ${ }^{9,10}$

$H$. influenzae es un pequeño bacilo gramnegativo que puede formar parte del microbioma normal del tracto respiratorio. Al romperse la membrana celular de la bacteria, se libera el lipopolisacárido, molécula que participa en el proceso inflamatorio y que en el suero se une a proteínas fijadoras de lipopolisacáridos (LBP, lipopolysaccharide-binding protein), complejo con alta especificidad a CD14. ${ }^{11}$ En los pacientes con sepsis, los niveles de LBP son altos. ${ }^{12}$

S. pneumoniae es un coco grampositivo y varios de sus antígenos han sido caracterizados, entre ellos la sustancia $C$ (ácido teicoico), la cual al unirse a una betaglobulina denominada proteína $C$ reactiva, presente en el suero de los pacientes, forma el complejo sustancia C-proteína C reactiva, que activa la 
cascada del complemento y, en consecuencia, la liberación de mediadores inflamatorios. ${ }^{13}$

Los neumococos producen neumolisina, la cual es liberada durante la lisis. Altas concentraciones de oligómeros de neumolisina son depositados sobre las membranas de las células del hospedero, donde forman poros y producen lisis celular. La neumolisina destruye los cilios de las células epiteliales respiratorias, rompe la monocapa de las células epiteliales del tracto respiratorio y disminuye la actividad bactericida y la migración de los neutrófilos; además, activa la vía clásica del complemento. La respuesta inflamatoria aguda también es desencadenada por diferentes estructuras bacterianas. El polisacárido de la pared celular activa la vía alterna del complemento y favorece la producción de las anafilotoxinas C3a y C5a, las cuales aumentan la permeabilidad vascular. ${ }^{13}$

Para la investigación que presentamos se formaron seis grupos de ratones con el propósito de demostrar que la infección bacteriana secundaria a la infección provocada por el virus de la influenza es la causa de la gravedad de la enfermedad respiratoria: un grupo control, uno infectado solo del virus de la influenza H1N1 pandémico, uno solo de $H$. influenzae y otro de S. pmeumoniae; así como dos grupos coinfectados del virus y cada una de esas bacterias, respectivamente. Se registraron los daños en órganos torácicos y abdominales, y se evaluó el proceso inflamatorio mediante la determinación de citocinas proinflamatorias en suero.

Si bien se ha registrado que las infecciones bacterianas secundarias causan la mayoría de las muertes durante las pandemias de influenza, poco se conoce sobre los mecanismos subyacentes responsables de la sinergia entre el virus de la influenza y las bacterias.

\section{Método}

Se utilizaron ratones macho de la cepa BALB/C, de ocho a 12 semanas de edad, distribuidos en seis grupos, uno control y cinco en los cuales por vía intranasal se inoculó virus de la influenza, $H$. influenzae o S. Pneumoniae, o el virus y una de las bacterias. Los microorganismos fueron diluidos en solución salina equilibrada (PBS, phosphate buffered saline):

- Grupo 1 o control: solo recibió PBS.

- Grupo 2: inoculado con virus de la influenza H1N1 pandémico, $1 \times 10^{5 / 50} \mu \mathrm{L}$ de PBS.

- Grupo 3: inoculado con S. pneumoniae ATCC $49614,1 \times 10^{7} / 500$ de $\mu$ L de PBS.
- Grupo 4: inoculado con H. influenzae ATCC 49766, $1 \times 10^{7} / 500 \mu \mathrm{L}$ de PBS.

- Grupo 5: inoculado con virus de la influenza y S. pneumoniae, $1 \times 10^{7} / 500 \mu \mathrm{L}$ de PBS.

- Grupo 6: inoculado con virus de la influenza y $H$. influenzae, $1 \times 10^{7 / 500} \mu \mathrm{L}$ de PBS.

Se confirmó el número de unidades formadoras de colonias (UFC) de las bacterias; S. pneumoniae se cultivó en agar sangre y $\mathrm{H}$. influenzae, en agar chocolate. La dosis real varió de $1.2 \times 10^{7}$ UFC a $1.4 \times 10^{7}$ UFC.

Los grupos fueron infectados al inicio del proyecto: los grupos 5 y 6 primero fueron infectados del virus de la influenza y a las 72 horas, de $S$. pneumoniae y H. influenzae, respectivamente.

El estudio se siguió por cuatro semanas; tres ratones de cada grupo fueron sacrificados cada cuatro días.

Diariamente se registro el peso de cada ratón y se evaluó actividad física, características del pelo y de los ojos.

Los ratones fueron anestesiados con una solución inyectable (Sedalpharma ${ }^{\circledR}$, Pet's Pharma, México). Posteriormente se obtuvo sangre del corazón, la cual fue procesada de forma convencional para la obtención de suero, que se guardó a $-20{ }^{\circ} \mathrm{C}$.

Se determinaron citocinas proinflamatorias en suero. La detección y cuantificación de las citocinas proinflamatorias interleucina (IL) $1 \beta$, IL-6 y factor de necrosis tumoral alfa (TNF $\alpha$, tumor necrosis factor $\alpha$ ) se realizaron mediante ELISA (enzyme-linked immunosorbent assay); se utilizó equipo de la marca PeproTech y se siguieron las indicaciones del fabricante.

\section{Resultados}

Al segundo día poscoinfección, los ratones coinfectados con virus de la influenza y $S$. pneumoniae presentaron pelo erizado. Al cuarto día poscoinfección se acentuó el signo del pelo en los grupos coinfectados 5 y 6 , además de presentar infecciones en ojos. Al sexto día poscoinfección, además de los datos anteriores, un ratón coinfectado de virus de la influenza y $S$. pneumoniae presentó dificultad respiratoria. Al séptimo día poscoinfección continuaron los signos y tres ratones con virus de la influenza y $S$. pneumoniae presentaron dificultad respiratoria. Los ratones con mayores efectos por la coinfección fueron sacrificados al octavo día poscoinfección. En el día 12 poscoinfección, algunos ratones continuaban con infección en ojos y pelo erizado. Los signos mencionados disminuyeron progresivamente en los ratones restantes, los cuales finalmente fueron sacrificados. 
Los ratones infectados solo de virus de la influenza H1N1, S. pneumoniae o $\mathrm{H}$. influenzae no presentaron datos de infección en órganos del tórax o cavidad abdominal.

En el estudio de los ratones sacrificados se identificaron distintas alteraciones según el momento de la poscoinfección por virus de la influenza y $S$. pneumoniae:

- A los cuatro días, en un ratón se identificó líquido en pleura; en uno, colapso de pulmón; en otro, hemorragia en íleon.

- A los ocho días, un ratón presentó líquido hemático en pleura, hemorragia en pulmón y nódulos blanquecinos en pulmón (Figura 1); en otro se observó hemorragia toracoabdominal y hemorragia en intestino (melena); y en uno más, vasodilatación en intestino (Figura 2);

- A los 12 días, un ratón presentó hemorragia en pulmones y otro, pequeñas hemorragias en ambos pulmones y vasodilatación en intestino (Figura 1).

La concentración en suero de las citocinas IL-1 $\beta$, IL-6 y TNF $\alpha$ se determinó a los cuatro días posteriores a la infección; se encontró disminución de las citocinas, tanto en los ratones con infección por virus H1N1, $H$. influenzae y $S$. pneumoniae, como en los ratones control. La disminución fue mayor en las muestras de sangre provenientes de los ratones con coinfección (Figura 3).

Si bien los niveles de las tres citocinas disminuyeron en los ratones control, permanecieron constantes durante las cuatro semanas, solo con pequeñas variaciones. Los ratones infectados de $H$. influenzae presentaron los valores más elevados de las tres citocinas y los infectados del virus de la influenza H1N1, los más bajos. Las concentraciones de las tres citocinas fueron más bajas a los cuatro días poscoinfección; sin embargo, se restablecieron en los ratones coinfectados de virus H1N1 y $\mathrm{H}$. influenzae, a diferencia de los ratones coinfectados de virus H1N y $S$. pneumoniae (Figura 3).

\section{Discusión}

Durante la pandemia de 1918, la coinfección bacteriana estuvo implicada en casi todas las muertes de personas infectadas del virus de la influenza. De igual manera sucedió en la pandemia de 2009: se observó coinfección bacteriana hasta en $34 \%$ de los pacientes con influenza pandémica A (H1N1) tratados en unidades de cuidados intensivos. Los patógenos que

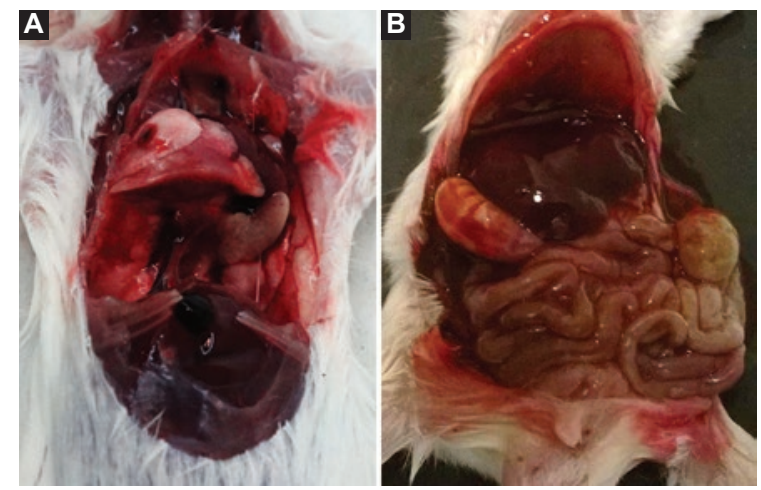

Figura 1. Hallazgos en un ratón a los ocho días poscoinfección por virus de la influenza y S. pneumoniae. A) Nódulos blanquecinos en pulmón. B) Hemorragia toracoabdominal y hepatoesplenomegalia.

colonizan la nasofaringe, (incluidos S. aureus, S. pneumoniae y $S$. pyogenes) se aislaron con mayor frecuencia. $^{14}$

En numerosos artículos se ha documentado que el virus de la influenza tipo A produce inflamación y necrosis en el epitelio del tracto respiratorio. En diferentes modelos animales, Wu et al..$^{15}$ encontraron que la coinfección afectaba la respuesta inmunitaria adaptativa: en comparación con los ratones infectados solo por el virus de la influenza, los ratones coinfectados por virus de la influenza y neumococo tuvieron una pérdida de peso corporal significativa; en el pulmón disminuyeron los niveles de IgG, IgM e IgA, así como el número de células plasmáticas, CD4 y B. La coinfección letal redujo el tamaño y el peso del bazo, así como el número de células B. En los ganglios linfáticos del mediastino, la coinfección letal disminuyó las células B del centro germinal, las células $T$ foliculares auxiliares y las células plasmáticas.

Walters et al. ${ }^{16}$ encontraron que los ratones coinfectados mostraban cambios histopatológicos en más de la mitad del parénquima alveolar, con espacios aéreos alveolares repletos de infiltrado inflamatorio, pleuritis supurativa aguda extensa, necrosis generalizada, bronquiolitis y abundantes trombos de fibrina en venas, vénulas y capilares. Los hallazgos anteriores fueron similares a los observados en nuestra investigación: los ratones coinfectados con el virus de la influenza H1N1 y $S$. pneumoniae mostraron líquido hemático en pleura, hemorragia y nódulos blanquecinos en pulmón. Walters et al. documentaron mayor expresión de genes que inhiben la función plaquetaria y la coagulación solo en los ratones coinfectados, datos que coinciden con los observados en nuestra investigación. 

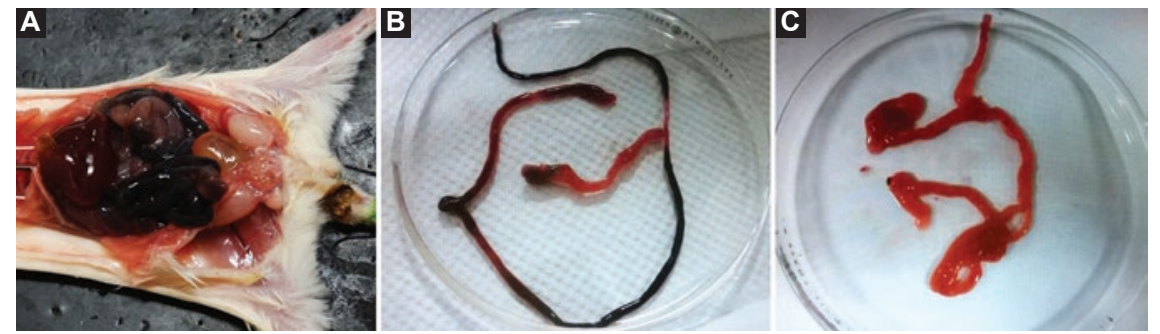

Figura 2. Hallazgos en un ratón a los ocho días poscoinfección por virus de la influenza y S. pneumoniae. A) Hemorragia toracoabdominal. B) Hemorragia en intestino (melena). C) Vasodilatación en intestino.

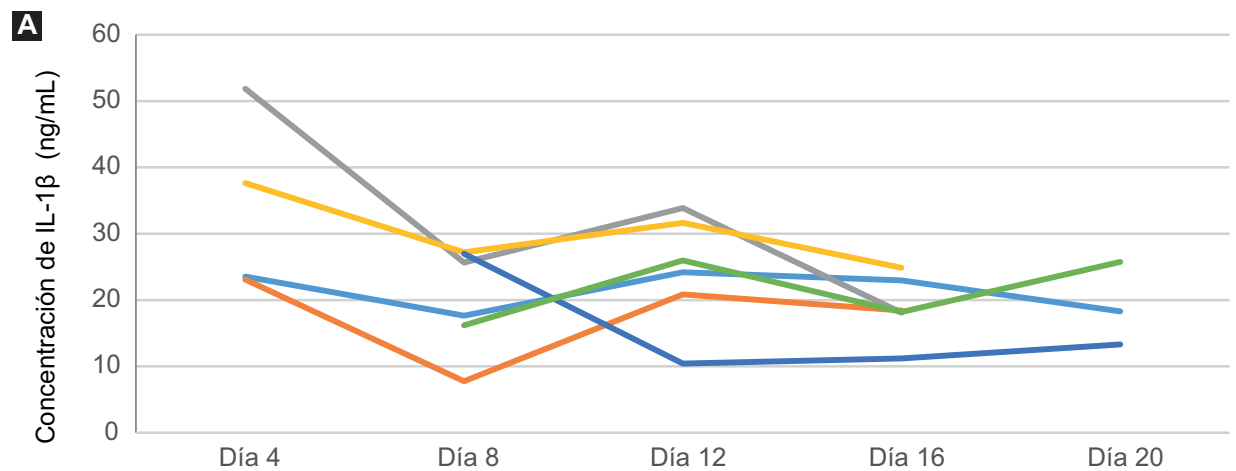

B

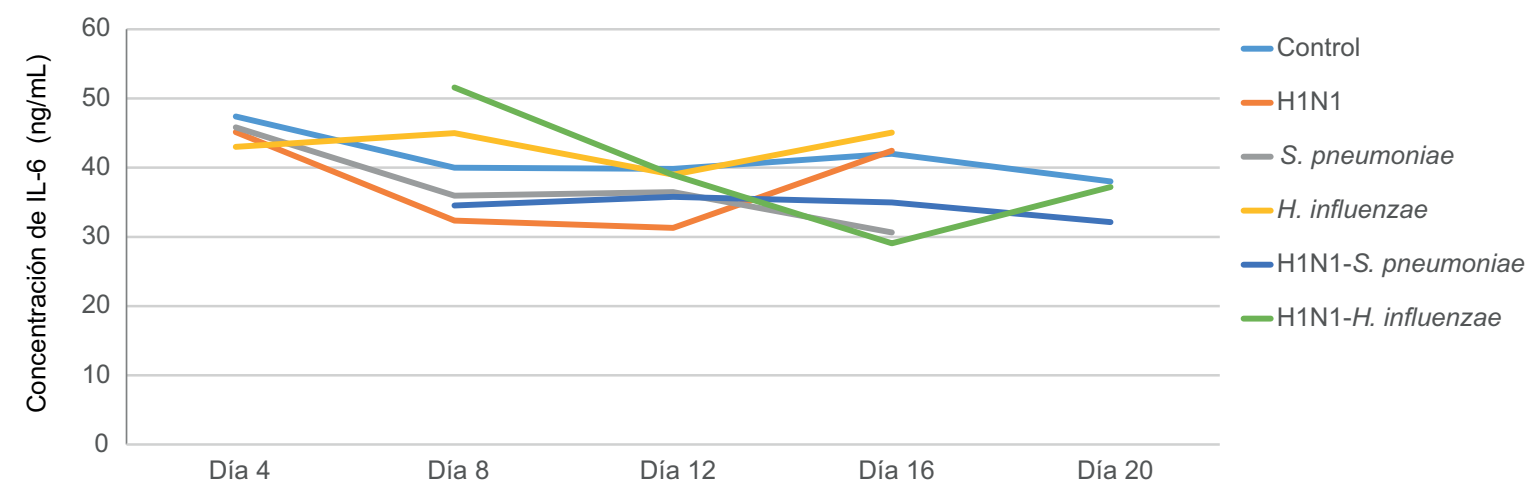

C

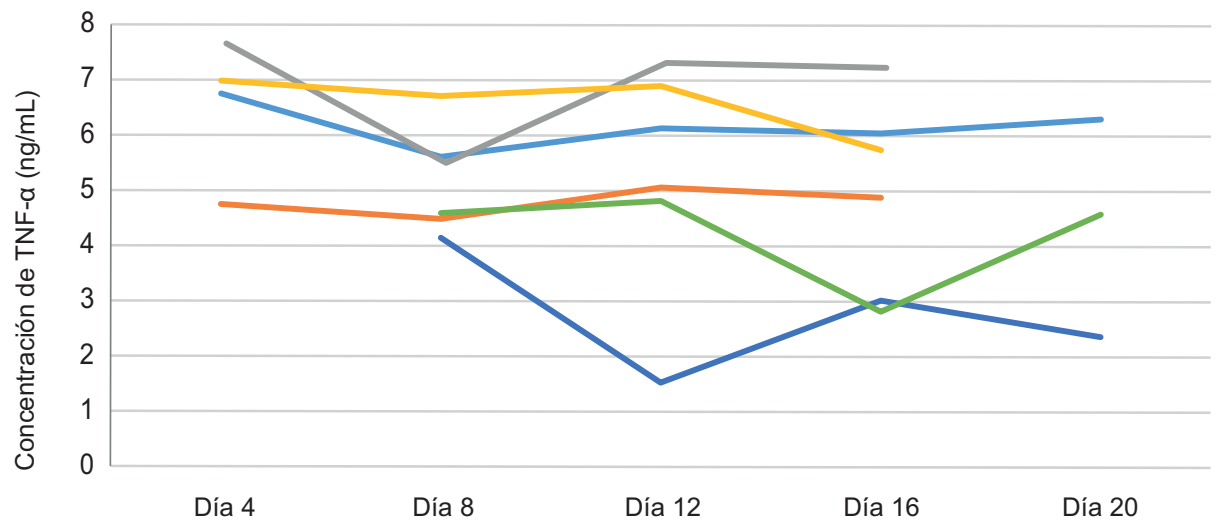

Figura 3. Concentración de citocinas en suero de ratones con el virus de la influenza H1N1 o con las bacterias S. pneumoniae y H. influenzae, y de ratones coinfectados por el virus de la influenza H1N1 y S. pneumoniae o virus de la influenza H1N1 y $H$. influenzae. A) Interleucina $1 \beta$. B) Interleucina 6. C) Factor de necrosis tumoral $\alpha$ (TNF- $\alpha$ ). 
En los ratones que estudiamos detectamos hemorragias torácica y abdominal, así como sangre digerida en intestino (melena), lo cual sugiere que las hemorragias se deben a incremento en el tiempo de coagulación, probablemente relacionado con mayor expresión en la inhibición de los genes involucrados en la función plaquetaria y en la coagulación, como lo demostraron Walters et al.

Es probable que los pacientes con infección por el virus de la influenza que fallecen hayan presentado coinfección bacteriana; S. pneumoniae pudo ocasionar alteraciones en el tiempo de coagulación, sangrado y pérdida de líquidos y, en consecuencia, mala irrigación sanguínea a los órganos, falla multisistémica, choque hipovolémico y muerte.

En un modelo murino coinfectado por el virus de la influenza H1N1 y S. pneumoniae, Wu et al..$^{15}$ demostraron disminución en los niveles de IgG, IgA e IgM específicas, así como en el número de células $\mathrm{B}$, células TCD4 y células plasmáticas en pulmón y órganos linfoides. En la investigación que realizamos, la concentración de citocinas proinflamatorias disminuyó en todos los grupos de ratones; ese decremento pudiera atribuirse a la disminución de las células productoras de dichas citocinas, como lo demostraron Wu et al.

\section{Conclusiones}

En nuestro estudio es probable que, particularmente en el grupo de ratones con daño torácico y abdominal, la inflamación y la necrosis causadas por el virus de la influenza hayan sido exacerbadas por S. pneumoniae y evolucionaran a alteración en el tiempo de coagulación y sangrado, tanto en órganos torácicos como de la cavidad abdominal.

Ahora bien, a la patogénesis de la coinfección contribuyen también factores de virulencia virales y bacterianos, así como del hospedero; por ello, la disminución de la morbilidad y la mortalidad dependerá de la prevención con las vacunas y del diagnóstico y tratamiento tempranos.

\section{Agradecimientos}

Esta investigación fue apoyada por la Facultad de Medicina de la Universidad Nacional Autónoma de México.

\section{Conflictos de intereses}

\section{Fuentes de financiamiento}

Para la presente investigación no se recibió beca específica de agencias de los sectores público, comercial o sin ánimo de lucro.

\section{Responsabilidades éticas}

Los autores declaran que los procedimientos realizados se llevaron a cabo conforme a las normas éticas de la experimentación en animales y de acuerdo con la Asociación Médica Mundial y la Declaración de Helsinki.

Confidencialidad de los datos. Los autores declaran que en este artículo no aparecen datos de pacientes.

Derecho a la privacidad y consentimiento informado. Los autores declaran que en este artículo no aparecen datos de pacientes.

\section{Referencias}

1. Centro Nacional para la Salud de la Infancia y Adolescencia [Internet]. México: Prevención de la mortalidad infantil 2007-2012. Secretaría de Salud; 2008. Disponible en: http://www.censia.salud.gob.mx/descargas/ infancia/pronaremi.pdf

2. Organización Mundial de la Salud [Internet]. Ginebra: Neumonía. 2016 Aug 02. Disponible en: https://www.who.int/es/news-room/fact-sheets/ detail/pneumonias

3. Morens DM, Taubenberger JK, Fauci AS. Predominant role of bacterial pneumonia as a cause of death in pandemic influenza: implications for pandemic influenza preparedness. J Infect Dis. 2008;198:962-970.

4. Chien YW, Klugman KP, Morens DM. Bacterial pathogens and death during the 1918 influenza pandemic. N Engl J Med. 2009;361:2582-2583.

5. McCullers JA. The co-pathogenesis of influenza viruses with bacteria in the lung. Nat Rev Microbiol. 2014;12:252-262.

6. Xiao YL, Kash JC, Beres SB, Sheng ZM, Musser JM, Taubenberger JK. High-throughput RNA sequencing of a formalin-fixed, paraffin-embedded autopsy lung tissue sample from the 1918 influenza pandemic. J Pathol. 2013;229:535-545. DOI:10.1002/path.4145.

7. McCullers JA. Insights into the interaction between influenza virus and pneumococcus. Clin Microbiol Rev. 2006;19:571-582.

8. Haste L, Hulland K, Bolton S, Yesilkaya H, McKechnie K, Andrew PW. Development and characterization of a long-term murine model of Streptococcus pneumoniae infection of the lower airways. Infect Immun. 2014; 82:3289-3298.

9. Leggiadro RJ. Bacterial coinfections in lung tissue specimens from fatal cases of 2009 pandemic influenza A (H1N1)-United States, May-August 2009. Pediatr Infect Dis J. 2009;58:1071-1074.

10. Lee EH, Wu C, Lee EU, Stoute A, Hanson H, Cook H A, et al. Fatalities associated with the $2009 \mathrm{H} 1 \mathrm{~N} 1$ influenza A virus in New York city. Clin Infect Dis. 2010; 50:1498-504.

11. Bosshart $\mathrm{H}$, Heinzelman M. Targeting bacterial endotoxin two sides of a coin. Ann N Y Acad Sci 2007;1096:1-17.

12. Myc A, Buck J, Gonin J, Reynolds B, Hammerling U, Emanuel D. The level of lipopolysaccharide-binding protein is significantly increased in plasma in patients with the systemic inflammatory response syndrome. Clin Diagn Lab Immunol.1997:19:113-136.

13. Castro AM. En Bacteriología médica basada en problemas. Segunda edición. México: El Manual Moderno. 2014. p: 37-88.

14. Chertow DS, Memoli MJ. Bacterial coinfection in influenza: a grand rounds review. JAMA. 2013;309:275-282.

15. Wu Y, Tu W, Lam KT, Chow KH, Ho PL, Guan Y, Peiris JS, et al. Lethal coinfection of influenza virus and Streptococcus pneumoniae lowers antibody response to influenza virus in lung and reduces numbers of germinal center B cells, T follicular helper cells, and plasma cells in mediastinal lymph node. J Virol. 2015;89:2013-223.

16. Walters KA, D'Agnillo F, Sheng ZM, Kindrachuk J, Schwartzman LM, Keustne RE, et al. 1918 pandemic influenza virus and Streptococcus pneumoniae coinfection results in activation of coagulation and widespread pulmonary thrombosis in mice and humans. J Pathol. 2016;238:85-97. 